\title{
An Improved Synthesis of optically Active Steroids
}

\author{
Tsunehiko Asako, Kentaro Hiraga, and Takuichi Miki \\ Chemical Research Laboratories, Central Research Division, Takeda \\ Chernical Industries, Ltd.1)
}

(Received June 8, 1972)

\begin{abstract}
$17 \alpha$-Hydroxy-3-methoxy-8,14-secoestra-1,3,5(10),9-tetraen-14-one (IIa) which is an intermediate for the total synthesis of estrogens has been optically resolved. The isomer which has unnatural configuration at $\mathrm{C}-13$ has been converted to estrapentaene 3-methyl ether (IVa) via the 9,14-epoxy intermediates (XI, XII, XIII, XV).
\end{abstract}

Wendler, et al. reduced $^{2)}$ 3-methoxy-8,14-secoestra-1,3,5(10),9-tetraene-14,17-dione (Ia) ${ }^{3}$ ) to rac-17 $\alpha$-hydroxy-3-methoxy-8,14-secoestra-1,3,5(10),9-tetraen-14-one (IIa) and, after resolution of the product, oxidized the enantiomorf having unnatural configuration at C-13 again to the starting diketone (Ia), thus permitting utilization of the unwanted isomer by circulating it in the resolution process via the oxidation-reduction pathway $(\mathrm{Ia} \leftrightarrows(+) \mathrm{IIa}$ $+(-)$ IIa).

We were performing a similar line of work and filed a patent ${ }^{\mathbf{4}}$ application earlier than Wendler, et al.

Treatment of Ia with sodium borohydride (lithium tri-t-butoxyaluminum hydride was used by Wendler, et al.) gave IIa of $\mathrm{mp} 72-73^{\circ}$ in good yield $(77.5 \%)$. Wendler, et al. blocked the hydroxyl group of IIa as the acetate before cyclization, whereas we performed direct cyclization of IIa into rac-3-methoxyestra-1,3,5(10),8,14-pentaen-17 $\alpha$-ol (IVa). IIa afforded a cyclized product $(\mathrm{IIIa})^{5,6}$ under a mild acidic condition, i.e. treatment with methanolic

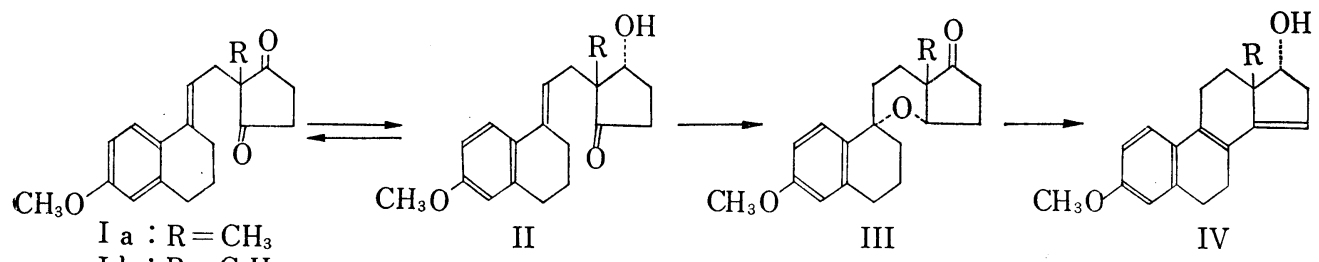

$\mathrm{I} b: \mathrm{R}=\mathrm{C}_{2} \mathrm{H}_{5}$
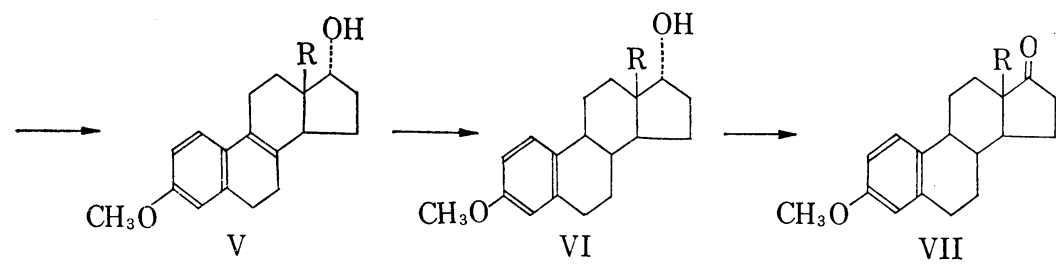

Chart 1

1) Location: Juso, Higashiyodogawa-ku, Osaka.

2) C.H. Kuo, D. Taub, and N.L. Wendler, Chem. Ind. (London), 1966, 1340; idem, J. Org. Chem., 33,3126 (1968).

3) P. Morand and J. Lyall, Chem. Rev., 68, 85 (1968), and references cited therein.

4) T. Miki and K. Hiraga, J. Patent 14781 (1970) [C.A., 73, 45688 (1970)].

5) T. Asako, K. Hiraga, and T. Miki, Chem. Pharm. Bull. (Tokyo), in press.

6) H. Gibian, K. Kieslich, H.J. Koch, H. Kosmol, C. Rufer, E. Sćhröder, and R. Vöslich, Tetrahedron Letters, 1966, 2321. 
hydrochloric acid at room temperature or with $p$-toluenesulfonic acid in benzene. IIa and IIIa were converted to IVa on treatment with hydrochloric acid in boiling methanol. IVa can be converted to rac-estrone methyl ether (VIIa) following the equation shown in Chart 1.

The same series of reactions as above were also carried out on the 13-ethyl analog of I (Chart 1).

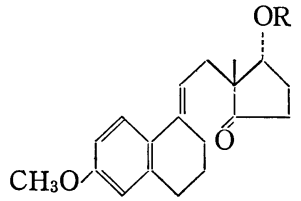

(-) $\mathrm{Ia}: \mathrm{R}=\mathrm{H},[\alpha]_{\mathrm{D}}=-83.6^{\circ}$

(-) VIII: $\mathrm{R}=\mathrm{COCH}_{2} \mathrm{CH}_{2} \mathrm{COOH},[\alpha]=-87.8^{\circ}$ (quinine salt, $[\alpha]_{\mathrm{D}}=+111.8^{\circ}$ )

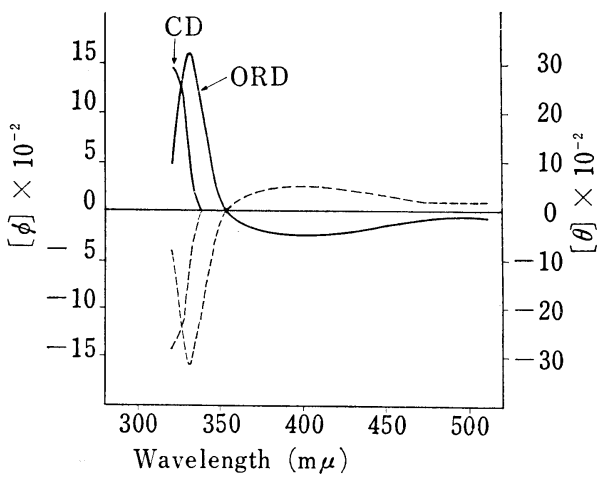

Fig. 1. ORD and CD Curves of IIa (in $\mathrm{EtOH}$ )

$$
\text { - }(-) \mathrm{IIa} \quad \cdots--\cdot(+) \mathrm{IIa}
$$

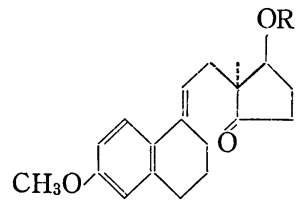

(t) IIa: $\mathrm{R}=\mathrm{H},[\alpha]_{\mathrm{D}}=+83.6^{\circ}$

(t) VIII: $\mathrm{R}=\mathrm{COCH}_{2} \mathrm{CH}_{2} \mathrm{COOH},[\alpha]_{\mathrm{D}}=+87.2^{\circ}$

(quinine salt, $[\alpha]_{\mathrm{D}}=+39.6^{\circ}$ )

Chart 2

IIa was ${ }^{\circ}$ converted to its hemisuccinate (VIII) and to the quinine salt for resolution. Removal of the quinine from the crystalline salt of $\mathrm{mp} 171-172^{\circ}$ with sulfuric acid followed by hydrolysis in a $\mathrm{KOH}$ solution gave dextrorotatory IIa (mp $102-104^{\circ}$ ). On the other hand, levorotatory IIa (mp 102-104 ${ }^{\circ}$ ) was obtained from the mother liquor of the quinine salt. Fig. 1 shows the optical rotatory dispersion (ORD) and circular dichroism (CD) curves of (-)IIa and $(+)$ IIa.

Both (-)IIa and $(+)$ IIa were respectively converted into estrone methyl ether (VII) and its antipode in the same manner as above, accordingly clarifying that (-)IIa has natural while $(+)$ IIa unnatural configuration. The latter $(+)$ IIa was converted into diketone (Ia) by oxidation with DMSO.

An attempt was then made to transform (+)IIa to a natural steroid skeleton by the route shown in Chart 3 . The acetate (IX) of $(+)$ II a was reduced with sodium borohydride in methanol to afford the $14 \beta$-ol (X), which was treated with $p$-toluenesulfonic acid in benzene at room temperature. The product was assigned to $13 \alpha$-methyl-9,14 $\beta$-epoxy structure (XI) because of the disappearance of the absorption maximum at $265 \mathrm{~m} \mu$ characteristic to the 3 methoxy-8,14-secoestra-1,3,5(10),9-tetraene system and the appearance of new absorption maxima at $278 \mathrm{~m} \mu$ and $286 \mathrm{~m} \mu$ ascribable to the 3 -methoxyestra-1,3,5(10)-triene system in the ultraviolet (UV) spectrum. The structure XI was also supported by the infrared (IR) spectrum which showed no absorption band ascribable to hydroxyl group. After purification by silica gel column chromatography, XI was hydrolyzed to the $17 \beta$-ol (XII) with potassium hydroxide in methanol. Oxidation of XII with chromium trioxide-pyridine complex afforded $13 \alpha$ methyl-9,14 $\beta$-epoxy-17-one (XIII) which showed an absorption band of a five-membered cyclic ketone at $1740 \mathrm{~cm}^{-1}$ in the IR spectrum. Treatment of XIII with hydrochloric acid in refluxing methanol yielded a crystalline material which was proved to be identical in all respects with (-) 3-methoxyestra-1,3,5(10),8,14-pentaen-17 $\alpha$-ol (IVa) obtained from (-)IIa by treatment with hydrochloric acid in boiling methanol. The over-all yield from $(+) \mathrm{IIa}$ to (-)IVa was $40 \%$. 


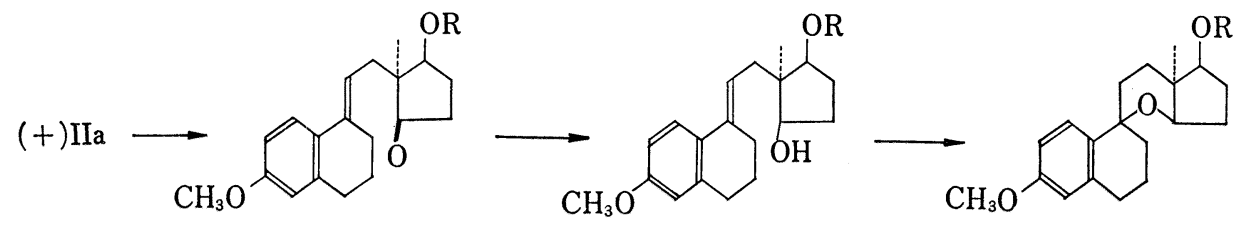

$$
\begin{array}{lll}
\text { IX }: R=\mathrm{COCH}_{3} & \mathrm{X}: \mathrm{R}=\mathrm{COCH}_{3} & \mathrm{XI}: \mathrm{R}=\mathrm{COCH}_{3} \\
(+) \mathrm{VIII}: \mathrm{R}=\mathrm{CO}\left(\mathrm{CH}_{2}\right)_{2} \mathrm{COOH} & \mathrm{XIV}: \mathrm{R}=\mathrm{CO}\left(\mathrm{CH}_{2}\right)_{2} \mathrm{COOH} & \mathrm{XV}: \mathrm{R}=\mathrm{CO}\left(\mathrm{CH}_{2}\right)_{2} \mathrm{COOH}
\end{array}
$$<smiles>COc1ccc2c(c1)CCc1cc(OC)ccc1-2</smiles>

Chart 3

In order to make the pathway shorter we tried to use the hemisuccinate (+)VIII of $(+)$ IIa mentioned above as a starting material. In this case (-)IVa was obtained in the yield of $30 \%$ from (+)IIa in a way similar to that for $17 \beta$-acetate series (Chart 3 ). The above results indicate that total synthesis of natural estrone is possible from both the enantiomeric intermediates, (+)IIa and (-)IIa.

\section{Experimental}

rac-17 $\alpha$-Hydroxy-3-methoxy-8,14-secoestra-1,3,5(10),9-tetraen-14-one (IIa)—To a solution of $20 \mathrm{~g}$ of 3-methoxy-8,14-secoestra-1,3,5(10),9-tetraene-14,17-dione (Ia) $\left.{ }^{3}\right)$ in 1 liter of $\mathrm{MeOH}$ was added portionwise $0.8 \mathrm{~g}$ of $\mathrm{NaBH}_{4}$ with stirring at $-20^{\circ}$. After $2 \mathrm{hr}, 3$ liter of water was added to the reaction mixture and the resulting precipitates were extracted with ether. The organic layer was washed with water, dried over $\mathrm{Na}_{2} \mathrm{SO}_{4}$ and concentrated to yield $19 \mathrm{~g}$ of rac-IIa. mp $72-73^{\circ}$ (from ether- $n$-hexane). Anal. Calcd. for $\mathrm{C}_{19} \mathrm{H}_{24} \mathrm{O}_{3}: \mathrm{C}, 76.00 ; \mathrm{H}, 8.00$. Found: C, 76.27; H, 7.92. IR $\boldsymbol{v}_{\max }^{\text {Nujol }} \mathrm{cm}^{-1}: 3450,1725$. UV $\lambda_{\max }^{\text {EtoH }} \mathrm{m} \mu(\varepsilon)$ : $266.5\left(1.93 \times 10^{4}\right)$.

rac-17 $\alpha$-Hydroxy-3-methoxy-8,14-seco-13-ethylgona-1,3,5(10),9-tetraen-14-one (IIb) was obtained as an oil from $\mathrm{Ib}^{3)}$ in a manner similar to that for IIa. IR $\nu_{\max }^{\mathrm{flm}} \mathrm{cm}^{-1}: 3400,1725$.

rac-3-Methoxy-9 $\alpha, 14 \alpha$-epoxy-8,14-secoestra-1,3,5(10)-trien-17-one (IIIa)—A solution of $0.4 \mathrm{~g}$ of rac$\mathrm{IIa}$ in $30 \mathrm{ml}$ of $\mathrm{MeOH}$ and $1 \mathrm{ml}$ of $6 \mathrm{~N} \mathrm{HCl}$ was allowed to stand for $4 \mathrm{hr}$ at room temperature. The reaction mixture was poured into water and extracted with ether. The organic layer was washed with water, a $5 \%$ aqueous $\mathrm{NaHCO}_{3}$ solution and water, dried and concentrated to yield $0.4 \mathrm{~g}$ of a yellow oil. When this oil was purified by column chromatography using $20 \mathrm{~g}$ of silica gel with the solvent system of benzeneether (9:1), $0.3 \mathrm{~g}$ of rac-IIIa was obtained. $\mathrm{mp} 81-83^{\circ}$ (from $\mathrm{MeOH}$ ). Anal. Calcd. for $\mathrm{C}_{19} \mathrm{H}_{24} \mathrm{O}_{3}: \mathrm{C}_{1}, 75.97$; $\mathrm{H}, 8.05$. Found: $\mathrm{C}, 75.95 ; \mathrm{H}, 7.94$. UV $\lambda_{\max }^{\mathrm{EtoH}} \mathrm{m} \mu(\varepsilon): 276\left(1.54 \times 10^{3}\right), 283\left(1.5 \times 10^{3}\right)$. IR $\nu_{\max }^{\mathrm{Najol}} \mathrm{cm}^{-1}$ : $1742,1620,1595,1509,836$. NMR $\delta_{\mathrm{ppm}}\left(\right.$ in $\left.\mathrm{CCl}_{4}\right): 0.92\left(3 \mathrm{H}\right.$, singlet, $\left.\mathrm{C}_{13}-\mathrm{CH}_{3}\right), 3.67\left(3 \mathrm{H}\right.$, singlet, $\left.\mathrm{OCH}_{3}\right)$, $4.07\left(1 \mathrm{H}\right.$, multiplet, $\left.\mathrm{C}_{14}-\mathrm{H}\right), 6.37\left(1 \mathrm{H}\right.$, doublet, $\left.\mathrm{C}_{4}-\mathrm{H}, J=2 \mathrm{~Hz}\right), 6.55\left(1 \mathrm{H}\right.$, quartet, $\left.\mathrm{C}_{2}-\mathrm{H}, J=2 \mathrm{~Hz} \& 8 \mathrm{~Hz}\right)$, $7.10\left(1 \mathrm{H}\right.$, doublet, $\left.\mathrm{C}_{1}-\mathrm{H}, J==8 \mathrm{~Hz}\right)$.

rac-3-Methoxy-9 $\alpha, 14 x$-epoxy-8,14-seco-13 $\beta$-ethylgona-1,3,5(10)-trien-14-one (IIIb) was similarly obtained from IIb. $\mathrm{mp} 64^{\circ}$ (from $n$-hexane). Anal. Calcd. for $\mathrm{C}_{20} \mathrm{H}_{26} \mathrm{O}_{3}: \mathrm{C}, 76.43 ; \mathrm{H}, 8.33$. Found: C, 76.51; $\mathrm{H}, 8.33$. IR $v_{\max }^{\mathrm{Nu}} \mathrm{cm}^{-1}: 1730$, no absorption of $\mathrm{OH}$.

rac-3-Methoxyestra-1,3,5(10),8,14-pentaen-17 $\alpha$-ol (IVa)_A solution of $0.15 \mathrm{~g}$ of rac-IIa in $10 \mathrm{mI}$ of $\mathrm{MeOH}$ and $0.5 \mathrm{ml}$ of conc. $\mathrm{HCl}$ was refluxed for 40 minutes. The reaction mixture was poured into water and extracted with ether. The organic layer was washed with water, a $5 \%$ aqueous $\mathrm{NaHCO}_{3}$ solution and water, dried and concentrated to yield crude crystals. Recrystallization from $\mathrm{MeOH}$ gave $0.12 \mathrm{~g}$ of $\mathrm{rac}-$ IVa. $\mathrm{mp} 101^{\circ}$. UV $\lambda_{\max }^{\mathrm{EtOH}} \mathrm{m} \mu(\varepsilon): 311\left(2.0 \times 10^{4}\right)$. IR $\nu_{\max }^{\mathrm{Nujol}} \mathrm{cm}^{-1}: 3400,1615,1510$. 
rac-3-Methoxyestra-1,3,5(10),8-tetraen-17 $\alpha$-ol (Va)__-A solution of $3 \mathrm{~g}$ of rac-IVa in $100 \mathrm{ml}$ of dioxane was shaken under a stream of hydrogen over Raney Ni. After absorption of $265 \mathrm{ml}$ of hydrogen, catalyst was filtered off and filtrate was concentrated to yield $2.2 \mathrm{~g}$ of $\mathrm{rac}$-Va. mp $159-161^{\circ}$ (from AcOEt). Anal. Calcd. for $\mathrm{C}_{19} \mathrm{H}_{24} \mathrm{O}_{2}: \mathrm{C}, 80.28 ; \mathrm{H}, 8.45$. Found: $\mathrm{C}, 79.97 ; \mathrm{H}, 8.41$. UV $\lambda_{\max }^{\text {EtoH }} \mathrm{m} \mu(\varepsilon): 277\left(1.57 \times 10^{4}\right)$.

From $0.8 \mathrm{~g}$ of $r a c$-IVb was similarly obtained $0.4 \mathrm{~g}$ of $r a c-3$-methoxy-13 $\beta$-ethylgona-1,3,5(10),8-tetraen-

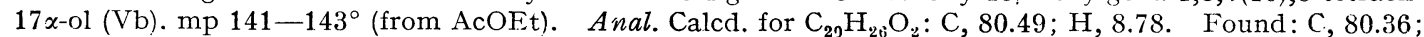
$\mathrm{H}, 8.64$. IR $\nu_{\max }^{\mathrm{Nujol}} \mathrm{cm}^{-1}: 3450$. UV $\lambda_{\max }^{\mathrm{Etor}} \mathrm{m} \mu(\varepsilon): 275\left(1.64 \times 10^{4}\right)$.

rac-3-Methoxyestra-1,3,5(10)-trien-17 $\alpha$-ol (VIa)_- To a solution of $0.4 \mathrm{~g}$ of $\mathrm{rac}$-Va in $20 \mathrm{ml}$ of dioxane, $40 \mathrm{ml}$ of ether and $40 \mathrm{ml}$ of liq. $\mathrm{NH}_{3}$ was added $0.7 \mathrm{~g}$ of $\mathrm{K}$ at $-50^{\circ}$ and the resulting mixture was stirred. at the same temperature for $2 \mathrm{hr}$. After addition of $2 \mathrm{~g}$ of $\mathrm{NH}_{4} \mathrm{Cl}, \mathrm{NH}_{3}$ was removed at room temperature. To the residue was added water and the mixture was extracted with ether. The organic layer was washed with water, dried over $\mathrm{Na}_{2} \mathrm{SO}_{4}$ and evaporated to yield $0.4 \mathrm{~g}$ of $\mathrm{rac}$-VIa. mp $94^{\circ}$ (from $n$-hexane). Anal. Calcd. for $\mathrm{C}_{29} \mathrm{H}_{26} \mathrm{O}_{2}: \mathrm{C}, 79.92 ; \mathrm{H}, 9.09$. Found: $\mathrm{C}, 79.98 ; \mathrm{H}, 9.15$. UV $\lambda_{\max }^{\text {Etor }} \mathrm{m} \mu(\varepsilon): 280\left(1.98 \times 10^{3}\right), 288$ $\left(1.9 \times 10^{3}\right)$.

rac-3-Methoxy-13 $\beta$-ethylgona-1,3,5(10)-trien-17 $\alpha$-ol (VIb) was obtained from $r a c$-Vb in a similar manner as rac-VIa. mp $71-73^{\circ}$ (from $\mathrm{MeOH}-\mathrm{H}_{2} \mathrm{O}$ ). Anal. Calcd. for $\mathrm{C}_{20} \mathrm{H}_{28} \mathrm{O}_{2} \cdot 1 / 2 \mathrm{H}_{2} \mathrm{O}$ : C, $77.67 ; \mathrm{H}, 9.39$. Found: $\mathrm{C}, 77.51 ; \mathrm{H}, 9.43$. UV $\lambda_{\max }^{\mathrm{EtOH}} \mathrm{m} \mu(\varepsilon): 279\left(1.94 \times 10^{3}\right), 288\left(1.83 \times 10^{3}\right)$.

rac-3-Methoxyestra-1,3,5(10)-trien-17-one (VIIa)-To a solution of $0.2 \mathrm{~g}$ of rac-VIa in $20 \mathrm{ml}$ of acetone was added $0.3 \mathrm{ml}$ of Jones reagent and the resulting mixture was allowed to stand for $10-15 \mathrm{~min}$ at room temperature. When water was added, crystals were precipitated out. $\mathrm{mp} 140^{\circ}$ (from $\mathrm{MeOH}$ ). Comparison with authentic sample ${ }^{3)}$ of $r a c-V I I a$ by $\mathrm{mp}$, IR showed the identity.

rac-3-Methoxy-13 $\beta$-ethylgona-1,3,5(10)-trien-17-one (VIIb) was obtained from $r a c$-VIb in a way similar to that for rac-VIIa. mp $126^{\circ}$. Comparison with authentic sample of rac-VIIb ${ }^{3}$ by $\mathrm{mp}$, IR showed the identity.

Hemisuccinate of rac-IIa (rac-VIII) — A solution of $6.85 \mathrm{~g}$ of rac-IIa and $16 \mathrm{~g}$ of succinic anhydride in $20 \mathrm{ml}$ of pyridine was stirred at $70-80^{\circ}$ for $10 \mathrm{hr}$. The reaction mixture was poured into water and extracted with AcOEt. The organic layer was washed with water, dried and concentrated to yield crude crystals, which were recrystallized from AcOEt to give $5 \mathrm{~g}$ of $\mathrm{rac}$-VIII as colorless platelet. $\mathrm{mp} 121-123^{\circ}$. Anal. Calcd. for $\mathrm{C}_{23} \mathrm{H}_{28} \mathrm{O}_{6}: \mathrm{C}, 68.98 ; \mathrm{H}, 7.04$. Found: $\mathrm{C}, 69.20 ; \mathrm{H}, 6.79$. UV $\lambda_{\max }^{\text {EtoH }} \mathrm{m} \mu(\varepsilon): 265\left(2.06 \times 10^{4}\right)$.

Quinine Salt of VIII-A solution of $2.43 \mathrm{~g}$ of quinine base in $20 \mathrm{ml}$ of acetone and $4 \mathrm{ml}$ of $\mathrm{MeOH}$ was added to a solution of $3 \mathrm{~g}$ of VIII in $25 \mathrm{ml}$ of acetone. With cooling, $3.5 \mathrm{~g}$ of crystals separated out. By recrystallization from MeOH-acetone, $2.1 \mathrm{~g}$ of quinine salt of $(+)$ VIII was obtained. $[\alpha]_{\mathrm{D}}^{23}+39.6^{\circ}(c==$ 1.0 in $\left.\mathrm{CHCl}_{3}\right)$. From the first mother liquor, $2.3 \mathrm{~g}$ of quinine salt of $(-)$ VIII was obtained as an oil. [ $\left.\alpha\right]_{\mathrm{D}}^{23}$ $+111.8^{\circ}\left(c=1.0\right.$ in $\left.\mathrm{CHCl}_{3}\right)$.

(-)17 $\alpha$-Hydroxy-3-methoxy-8.14-secoestra-1,3,5(10),9-tetraen-14-one 17-Hemisuccinate (VIII)--2.2 g of the oily quinine salt obtained above was dissolved in $30 \mathrm{ml}$ of $\mathrm{CHCl}_{3}$. This solution was washed with $20 \mathrm{ml}$ of a $10 \%$ aqueous $\mathrm{H}_{2} \mathrm{SO}_{4}$ solution three times and then water, dried and concentrated to yield $1.6 \mathrm{~g}$ of $(-)$ VIII as an oil. $[\alpha]_{\mathrm{D}}^{24}-87.8^{\circ}\left(c=1.2\right.$ in $\left.\mathrm{CHCl}_{3}\right)$. In a similar manner, $0.9 \mathrm{~g} \mathrm{cf}(+)$ VIII was obtained as an oil from $1.4 \mathrm{~g}$ of crystalline quinine salt. $[\alpha]_{\mathrm{D}}+87.2^{\circ}\left(c=1.2\right.$ in $\left.\mathrm{CHCl}_{3}\right)$.

(-) $17 \alpha$-Hydroxy-3-methoxy-8,14-secoestra-1,3,5(10),9-tetraen-14-one (IIa)_— To a solution of $1.5 \mathrm{~g}$ of (-)VIII in $20 \mathrm{ml}$ of $\mathrm{MeOH}$ was added $14 \mathrm{ml}$ of $10 \mathrm{~N}$ aqueous $\mathrm{KOH}$ solution with ice cooling. After stirring for $1 \mathrm{hr}$, the reaction mixture was poured into water and extracted with ether. The organic layer was washed with water, dried and concentrated to afford $0.86 \mathrm{~g}$ of $(-) \mathrm{IIa}$ as needles. mp $102-103^{\circ}$ (from $\left.\mathrm{MeOH}\right)$. $[\alpha]_{\mathrm{I}}^{24}$ $-83.6^{\circ}\left(c=1.0\right.$ in $\left.\mathrm{CHCl}_{3}\right)$. In a similar way, $0.5 \mathrm{~g}$ of $(+) \mathrm{IIa}$ was obtained by hydrolysis of $0.8 \mathrm{~g}$ of $(+) \mathrm{VIII}$ as needles. $[\alpha]_{\mathrm{D}}^{24}+83.6^{\circ}\left(c=1.0\right.$ in $\left.\mathrm{CHCl}_{3}\right)$.

(-)3-Methoxyestra-1,3,5(10),8,14-pentaen-17 $\alpha$-ol (IVa)-0.6 $\mathrm{g}$ of (-) IIa was dissolved in $16 \mathrm{ml}$ of $\mathrm{MeOH}$ and to this solution was added $2.7 \mathrm{ml}$ of conc. $\mathrm{HCl}$. The resulting mixture was refluxed gently with stirring for $40 \mathrm{~min}$, then poured into water, extracted with benzene, washed with water and dried over $\mathrm{Na}_{2} \mathrm{SO}_{4}$. The solvent was evaporated to afford crude crystals. Recrystallization from a small volume of $\mathrm{MeOH}$ gave $0.55 \mathrm{~g}$ of $(-) \mathrm{IVa}$ as colorless needles. mp $63-64^{\circ}$. $[\alpha]_{\mathrm{D}}^{24}-192.6^{\circ}\left(c=1.0\right.$ in $\left.\mathrm{CHCl}_{3}\right)$. In a similar manner, $0.4 \mathrm{~g}$ of $(+) \mathrm{IVa}$ was obtained from $0.45 \mathrm{~g}$ of $(+)$ IIa. $\mathrm{mp} 63-64^{\circ} \cdot[\alpha]_{\mathrm{D}}^{24}+190.8^{\circ}(c=$ 0.5 in $\mathrm{CHCl}_{3}$ ).

(-)3-Methoxyestra-1,3,5(10),8-tetraen-17 $\alpha$-ol (Va)_-A solution of $0.6 \mathrm{~g}$ of $(-) \mathrm{IV}$ in $30 \mathrm{ml}$ of dioxane was shaken under a stream of hydrogen over Raney Ni. After $47 \mathrm{ml}$ of hydrogen was absorbed, catalyst was filtered off and the filtrate was concentrated to yield crude crystals. Recrystallization from ether afforded $0.5 \mathrm{~g}$ of $(-) \mathrm{Va}$ as plates. $\mathrm{mp} 113-116^{\circ}$. $[\alpha]_{\mathrm{D}}^{24}-31.5^{\circ}\left(c=1.0\right.$ in $\left.\mathrm{CHCl}_{3}\right)$.

In a similar manner, $0.4 \mathrm{~g}$ of $(+) \mathrm{Va}$ was obtained as an oil. $[\alpha]_{\mathrm{D}}^{24}+42.3^{\circ}\left(c=1.0\right.$ in $\left.\mathrm{CHCl}_{3}\right)$.

$(+) 3$-Methoxyestra-1,3,5(10)-trien-17 $\alpha$-ol (VIa)-To a solution of $0.4 \mathrm{~g}$ of (-) Va in $20 \mathrm{ml}$ of dioxane, $40 \mathrm{ml}$ of tetrahydrofurane and $250 \mathrm{ml}$ of liq. $\mathrm{NH}_{3}$ was added portionwise $2 \mathrm{~g}$ of potassium at $-30--50^{\circ}$ and the resulting mixture was stirred at the same temperature for $2 \mathrm{hr}$. Decomposition of excess of potassium with $\mathrm{NH}_{4} \mathrm{Cl}$ followed by removal of liq. $\mathrm{NH}_{3}$ afforded a syrup. To this residue was added water and the resulting mixture was extracted with benzene. The organic layer was washed with water, dried and concentrated to afford $0.35 \mathrm{~g}$ of $(+) \mathrm{VIa}$ as an oil. $[\alpha]_{\mathrm{D}}^{24}+13.5^{\circ}\left(c=1.0 \mathrm{in} \mathrm{CHCl}_{3}\right)$. In a similar manner, $0.33 \mathrm{~g}$ 
of $(-)$ VIa was obtained from $0.4 \mathrm{~g}$ of $(+)$ Va. mp $96-100^{\circ} \cdot[\alpha]_{\mathrm{D}}^{24}-17.6^{\circ}\left(c=0.5\right.$ in $\left.\mathrm{CHCl}_{3}\right)$.

(+)3-Methoxyestra-1,3,5(10)-trien-17-one (VIIa)_-To a solution of $0.2 \mathrm{~g}$ of $(+)$ VIa in $20 \mathrm{ml}$ of acetone was added dropwise $0.25 \mathrm{ml}$ of Jones reagent at room temperature with vigorous stirring. After excess reagent was decomposed with $\mathrm{MeOH}$, water was added into the mixture to give crystals. Recrystallization from EtOH gave $0.18 \mathrm{~g}$ of $\left(+\mid\right.$ VIIa. $\mathrm{mp} 165-168^{\circ}$. $[\alpha]_{0}^{24}+144.2^{\circ} .\left(c=1.0\right.$ in $\left.\mathrm{CHCl}_{3}\right)$. Comparison of this substance with authentic sample of estrone methyl ether showed an identity. In a similar manner, $0.25 \mathrm{~g}$ of (-)VIIa was obtained from $0.3 \mathrm{~g}$ of $(-) \mathrm{VIa}$. mp $164-168^{\circ}$. $[\alpha]_{\mathrm{D}}^{24}-147.6^{\circ}\left(c=1.0\right.$ in $\left.\mathrm{CHCl}_{3}\right)$.

Reconversion of (+)IIa into I-To a solution of $3.6 \mathrm{~g}$ of $(+) \mathrm{II}$ Ta in $18 \mathrm{ml}$ of benzene, $18 \mathrm{ml}$ of DMSO and $9.6 \mathrm{ml}$ of pyridine were added $0.48 \mathrm{ml}$ of $\mathrm{CF}_{3} \mathrm{COOH}$ and $6 \mathrm{~g}$ of $\mathrm{DCC}$ and the resulting mixture was stirred at room temperature for $14 \mathrm{hr}$. Then $150 \mathrm{ml}$ of ether was added and subsequent addition of $4 \mathrm{~g}$ of oxalic acid, $100 \mathrm{ml}$ of $\mathrm{MeOH}$ and water gave precipitates, which were filtered off. The organic layer was separated and washed with an aqueous $\mathrm{NaHCO}_{3}$ solution and water, dried and concentrated. The residue was chromatographed on $100 \mathrm{~g}$ of silica gel with the solvent system of benzene-ether $(10: 1)$ to afford $2.3 \mathrm{~g}$ of $\mathrm{I}$. $\mathrm{mp}$ $78^{\circ}$. $0.2 \mathrm{~g}$ of $(+) \mathrm{II}$ a was recovered.

(+)17 $\beta$-Acetoxy-3-methoxy-8,14-seco-13 $\alpha$-estra-1,3,5(10),9-tetraen-17-one (IX)-To a solution of $2.2 \mathrm{~g}$ of ( + ) II in $14 \mathrm{ml}$ of pyridine was added $3.2 \mathrm{ml}$ of acetic anhydride and the mixture was kept at $50^{\circ}$ for $2 \mathrm{hr}$. The reaction mixture was poured into ice-water and extracted with ether. The organic layer was washed with dil. $\mathrm{HCl}$, a $5 \%$ aqueous $\mathrm{NaHCO}_{3}$ solution and water, dried and evaporated to afford $2.4 \mathrm{~g}$ of $(+) \mathrm{IX}$ as a pale yellow oil. $[\alpha]_{\mathrm{D}}^{26}+71.0^{\circ}\left(c=1.0\right.$ in $\left.\mathrm{CHCl}_{3}\right)$. IR $\nu_{\max }^{\mathrm{film}} \mathrm{cm}^{-1}: 1740,1610,1500$. UV $\lambda_{\max }^{\mathrm{EtOH}} \mathrm{m} \mu(\varepsilon): 265$ $\left(2.6 \times 10^{4}\right)$

$(+) 17 \beta$-Acetoxy-3-nethoxy-8,14-seco-13 $\alpha$-estra-1,3,5(10),9-tetraen-17 $\alpha$-ol $(\mathrm{X})$ - To a solution of $2.4 \mathrm{~g}$ of $(+) \mathrm{IX}$ in $100 \mathrm{ml}$ of $\mathrm{MeOH}$ was slowly added $0.3 \mathrm{~g}$ of $\mathrm{NaBH}_{4}$ at $-20--30^{\circ}$ and the mixture was stirred at this temperature for $1.5 \mathrm{hr}$. The reaction mixture was poured into water and extracted with ether. The ether solution was washed with water, dried and evaporated to give $2.4 \mathrm{~g}$ of $(+) \mathrm{X}$ as an oily material. $[\alpha]_{\mathrm{D}}^{25}+11.1^{\circ}\left(c=1.0\right.$ in $\left.\mathrm{CHCl}_{3}\right)$. IR $v_{\max }^{\mathrm{fllm}} \mathrm{cm}^{-1}: 3450,1730,1610,1490$.

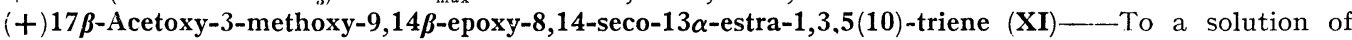
$2.4 \mathrm{~g}$ of $(+) \mathrm{X}$ in $80 \mathrm{ml}$ of benzene was added $0.05 \mathrm{~g}$ of $p$. TsOH and the mixture was allowed to stand at room temperature over night. After washing with a sat. aqueous $\mathrm{NaHCO}_{3}$ solution, and then water, the organic layer was dried over $\mathrm{Na}_{2} \mathrm{SO}_{4}$ and evaporated. The residue was chromatographed on $10 \mathrm{~g}$ of silica gel. Elution with benzene gave $2.3 \mathrm{~g}$ of an oily material. $[\alpha]_{\mathrm{D}}^{25}+20.8^{\circ}\left(c=1.0\right.$ in $\left.\mathrm{CHCl}_{3}\right) . \quad \mathrm{IR}_{\max }^{\mathrm{fl1m}} \mathrm{cm}^{-1}$ : $1730,1610,1500$. UV $\lambda_{\max }^{\mathrm{EtOH}} \mathrm{m} \mu(\varepsilon): 277\left(1.82 \times 10^{3}\right), 283\left(1.72 \times 10^{3}\right)$.

3-Methoxy-9,14 $\beta$-epoxy-8,14-seco-13 $\alpha$-estra-1,3,5(10)-trien-17 $\beta$-ol (XII)——To a solution of $2.3 \mathrm{~g}$ of $(+) \mathrm{XI}$ in $30 \mathrm{ml}$ of $\mathrm{EtOH}$ was added $20 \mathrm{ml}$ of a ethanolic solution of $1 \mathrm{~N} \mathrm{KOH}$ and the reaction mixture was allowed to stand at room temperature overnight. The reaction mixture was poured into water and extracted with ether. The extracts were combined and washed with water, dried and evaporated to give $1.9 \mathrm{~g}$ of XII as an oily material. IR $\nu_{\max }^{\mathrm{fllm}} \mathrm{cm}^{-1}: 3400,1610$.

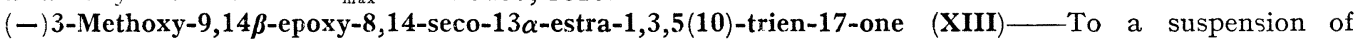
$\mathrm{CrO}_{3}$-pyridine complex prepared from $1.3 \mathrm{~g}$ of $\mathrm{CrO}_{3}$ and $30 \mathrm{ml}$ of pyridine was added dropwise a solution of $1.9 \mathrm{~g}$ of XII in $10 \mathrm{ml}$ of pvridine and the mixture was stirred at room temperature for $2 \mathrm{hr}$. Then the reaction mixture was poured into ice-water and extracted with ether. The ether solution was washed with dil. $\mathrm{H}_{2} \mathrm{SO}_{4}$, saturated $\mathrm{NaHCO}_{3}$ solution and water, dried over $\mathrm{Na}_{4} \mathrm{SO}_{4}$ and evaporated to give an oily residue which was chromatographed on $30 \mathrm{~g}$ of silica gel. Fractions eluted with benzene-ether $(50: 1)$ afforded $1.5 \mathrm{~g}$ of $(-)$ XIII as an oily material. $[\alpha]_{\mathrm{D}}^{26}-32.7^{\circ}\left(c=1.0 \mathrm{in} \mathrm{CHCl}_{3}\right)$. IR $\nu_{\max }^{\mathrm{rilm}} \mathrm{cm}^{-1}: 1740,1610,1500$.

(-)3-Methoxyestra-1,3,5(10),8,14-pentaen-17 $\alpha$-ol (IVa)—To a solution of $1.5 \mathrm{~g}$ of (-)XIII in $30 \mathrm{ml}$ of $\mathrm{MeOH}$ was added $5 \mathrm{ml}$ of conc. $\mathrm{HCl}$ and the solution was refluxed for $30 \mathrm{~min}$. The reaction mixture was poured into water and extracted with ether. The ether solution was washed with saturated $\mathrm{NaHCO}_{3}$ solution, water, dried over $\mathrm{Na}_{2} \mathrm{SO}_{4}$ and evaporated to give $1.5 \mathrm{~g}$ of a yellow oil, from which $0.8 \mathrm{~g}$ of crude crystals of (-)IVa were obtained. Recrystallization from $\mathrm{MeOH}$ afforded the pure sample. mp $59-61^{\circ}$. $[\alpha]_{D}^{26}-194^{\circ}\left(c=1.0\right.$ in $\left.\mathrm{CHCl}_{3}\right) . \quad \mathrm{UV} \lambda_{\max }^{\mathrm{EtoH}} \mathrm{m} \mu(\varepsilon): 310\left(2.78 \times 10^{4}\right)$.

XII from (t)VIII - To a solution of $2.2 \mathrm{~g}$ of $(+)$ VIII in $22 \mathrm{ml}$ of pyridine and $20 \mathrm{ml}$ of water was added $0.4 \mathrm{~g}$ of $\mathrm{NaBH}_{4}$ and the mixture was stirred at $0^{\circ}$ for $1 \mathrm{hr}$. The reaction mixture was poured into water. After adjusting the aqueous solution at $\mathrm{pH} 5.0$ with $\mathrm{HCl}$, the mixture was extracted with ether. The ether solution was washed with dil. $\mathrm{HCl}$ and water, dried and evaporated. To a solution of the residue (XIV) in dry benzene was added $0.1 \mathrm{~g}$ of $p-\mathrm{TsOH}$ and the solution was allowed to stand overnight at room temperature. The solution was extracted with a saturated $\mathrm{NaHCO}_{3}$ solution and to the water layer was added $10 \mathrm{~g}$ of $\mathrm{KOH}$, then $500 \mathrm{ml}$ of water. This mixture was extracted with ether and the ether solution was washed with water, dried and evaporated to give $1.6 \mathrm{~g}$ of a yellow oil which was chromatographed on silica gel. Elıtion with benzene-ether $(20: 1)$ gave $1 \mathrm{~g}$ of XII as a pale yellow oil.

Acknowledgement The authors wish to thank Drs. S. Tatsuoka and Y. Abe for their constant encouragement throughout this work. 